\title{
SENTENCE AND ITS PARTS. A PSYCHOLINGUistiC THEORY OF SYNTACTIC VALUE*
}

\author{
Lia Formigari \\ Emerita, Sapienza Università di Roma
}

\section{Résumé}

Se basant en particulier sur les textes de Georg von der Gabelentz, Hermann Paul et Christoph Sigwart, l'article se propose d'analyser la façon dont les catégories grammaticales et les catégories psychologiques se situent à l'intérieur de la proposition. L'intervention vise plus spécifiquement à établir jusqu'à quel point la nouvelle méthode d'analyse syntaxique proposée par ces auteurs est responsable d'une nouvelle vision des rôles du locuteur et/ ou du contexte dans le repérage des fonctions ultimes des constituants de la proposition. La méthode de la psychologie génétique est examinée du point de vue du débat sur les ellipses et sur les subjectlose Sätze.

\section{Mots-clés}

Ellipse, Gabelentz, impersonnels, Paul, pragmatique, Sigwart, théories syntactiques

\section{Abstract}

Focusing on the works of Georg von der Gabelentz, Hermann Paul and Christoph Sigwart, the paper analyses the different ways in which logically or psychologically based categories are related to the structure of sentences. In particular, it aims at establishing the extent to which the new model of syntactic analysis is connected with a new appraisal of the role of the speaker and/or the context, in determining the final functions of the various sentence members. The method of genetic psychology is examined here from the vantage point of the debate on subjectlose Sätze.

\section{Keywords}

Ellipse, Gabelentz, impersonals, Paul, pragmatics, Sigwart, syntactic theories

* Translations by Gabriel Poole, german texts included. 
Every verbal expression, word or form, has a syntactic value: the living speech is never used to express a single concept but, rather, to communicate a group of concepts related to one another, a thought. The way in which, within this group, the concepts are ordered, connected and distinguished is crucial for the functions of the words and their parts, and for delimiting the parts of discourse (Gabelentz 1874, p. 132).

I shall borrow from Giorgio Graffi (2001, p. $112 \mathrm{ff}$.) the distinction between the analytic and the holistic aspect of sentences, respectively derived from the two defining characteristics Priscian attributes to them, namely, that of being ordered successions of elements (subject and predicate) and of expressing a complete thought. The mutual inherence of these two aspects had been taken for granted by traditional general grammar, which equated the grammatical structure of the sentence with the deep structure of categorical judgement. It was called into question by 19th century genetic psychology, which tended to take as a model for sentences apperception acts, that is, psychological acts of inclusion of new information in a representational aggregation already consolidated by past experience. Apperception was conceived as an immediate experiential act of spontaneous categorization, the mind's first strategy in grasping and elaborating percepts. It was not considered a logical procedure, other than in the sense of being a function of a natural "logic", manipulating representations instead of applying formal rules.

Steinthal called Erkennungsatz ("identification sentence") the connection of two representations or representational aggregations. An identification sentence does not necessarily imply a logical judgement or an ontological commitment on the part of the speaker (Steinthal 1855, p. 152), nor does it generate the grammatical categories of name and verb, or the syntactical roles of subject and predicate, which characterize judgements. In the "dual synthesis of the new intuition with the previous intuitions and the word", the fusion of the new intuition with the preexisting mass "is for us the copula", even if, from a grammatical point of view, "the latter does not yet exist [...] neither does any verb" (ibid., p. 325). At most a hint of the distinction between subject and predicate is contained in identification sentences, because all apperception acts imply a connection between an already consolidated representation (appercipiens) and a new datum (appercipiendum). Thus, an apperception act contains in nuce the two terms that will verbally manifest themselves respectively as subject and predicate (Steinthal 1881, p. 14; see p. 171). 
In short, every apperception is based on two terms which, however, are articulated as the syntactic constituents of the sentence only after the threshold of language is crossed. This is a "universally human" fact, indipendent of the diversity of languages and their having or not a nominative case or a finite verb, because subject and predicate "are already present in the representation itself" (ibid., p. 446-447).

\section{THE CONSTITUENT’S ROLES-PLAYING GAMES}

For the followers of Steinthal, the joint presence of subject and predicate was the indisputable condition for the sentence to be complete. However, the two constituents were not identified on the basis of their analytical order, but of their role in pre-verbal synthesis, as appercipiendum or appercipiens. Roles are suggested by the speaker's focus on one or the other of the two elements, by the way the speaker suggests their saliency through intonation or by other means. The psychological subject and predicate may or may not coincide with the grammatical subject and predicate, but their joint presence is in any case necessary for the expression of a complete thought.

The term role (Rolle) was first used by Steinthal in his analysis of the sentence $(1855$, p. $168 f f ., 197 f f$.) in which he distinguishes sentence from judgement (the former being governed by grammatical criteria, which are not logical laws) and points out the differences between the procedures of logic (which is not a genetic science and takes terms as such independently of their origin) and psychology (which focuses instead on their genesis). The variability of the grammatical roles of the various constituents of discourse and of their hierarchy becomes evident in the analysis of sentences. If, for example, we transform the sentence: "an affectionate father educates his children strictly", in the sentence: "a father who loves his children gives them an education that is strict",

the roles, which in the previous version were mixed, are now clearly distinct. Yet, thanks to the conjunctions, their unity is still evident. A father is twice the subject, once as father and once as who; loves is a predicate of who and attribute of father; gives them an education is a predicate but, expressed as that, is the subject [...]. This shows that the difference between simple and complex sentences is purely grammatical, it does not have a logical foundation and cannot be reduced to logical criteria (Steinthal 1855, p. 198).

Just as the grammatical roles of the constituents do not necessarily correspond to their logical roles, they also do not necessarily correspond to their psychological, that is, their contextual and conversational ones. In the sentence: it is iron that transmits it [electricity], the focus of attention (the appercipiendum, the subject, what we are dealing with) is not iron but it. If we say, instead, it is through it [iron] that electricity is transmitted, the role of the subject is played by through 
$i t$. As one can see, the notion of role implies that of a "scene" in which each role is represented and this scene is the context, situational or conversational, of the utterance.

Gabelentz too speaks of roles in this sense $(1869$, p. 380; 1891, p. 370), approaching the question from the point of view of verbal interaction. As syntactic categories, subject (or theme: 1874, p. 137; 1891, p. 373) and predicate do not depend on the grammatical category of the constituents but on the function that the speaker attributes to them in the message: a choice that "can be very free, but certainly not casual: it is significant" $\left(1901^{2}\right.$, p. 369). These functions are "first, that of focusing the [hearer's] attention, his thinking, on something. I call psychological subject that on which I will have attracted the [hearer's] thinking, psychological predicate that which I intend to have him think of it" $(1869$, p. 378).

The topicalization of one constituent or the other is never indifferent from a semantic perspective. The two expressions-Napoleon was defeated in the battle of Leipzig, and In the battle of Leipzig Napoleon was defeated- have a different meaning due to the fact that the psychological subject -the constituent on which the speaker wishes to attract the attention of the hearer- is Napoleon in the first case and the battle of Leipzig in the second. The same holds for the sentences yesterday was Sunday and Sunday was yesterday. The distance between Leipzig and Dresden can be expressed in different forms semantically non equivalent, because of the different roles assigned to the names of the two cities. a) Leipzig ist von Dresden... b) Dresden ist von Leipzig... c) von Leipzig ist Dresden... d) von Dresden ist Leipzig...115 Kilometer entfernt, where a) and c) say something about Leipzig, b) and d) say something about Dresden; but in a) and b) the city that functions as subject is implicitly taken as arrival point and in c) and d) as starting point.

\section{HOW TO FILL THE VACANT ROLE: THE RESOLUTION OF THE ELLIPSE}

Stage metaphors like the ones used by Steinthal and Gabelentz are common in the debates whose history we are retracing. The nature of syntactic categories depends on the role they play in the scene of the enunciation. Or, more precisely, on the role that the speaker imposes on them using the phonosymbolic and morphosyntactic strategies typical of his native language. The way the speaker organizes the enunciation determines the salience assigned in the scene to one or the other constituent of the sentence. This is a principle that operates in competition with the laws of grammar.

Stage metaphors were not new in language theories. Thought and speech had been compared by Jacobi (1791, p. vi), and later by Reinhold (1812, p. 251252), to the Menaechmi, the identical twins in Plautus' comedy, the source of endless misunderstandings on the stage of philosophy. Now, about one century 
later, the drama seems to be reaching his conclusion. The twinning between logic and language, based on the idea of a syntax of sentences modeled on categorical judgements, is being questioned. Thought itself has lost its monological character, and psychology tends to highlight the variety of ist conscious and unconscious components and the complexity of its functions.

The two questions I will deal with in this paper -ellipses and impersonal sentences-can be viewed as two different ways of responding to the same problem: how the listener mentally integrates an incomplete expression in order to recreate the completeness of the original thought. Bühler's idea of synsemantic field also originated from his reflection on the ellipse, this "old crux of the theoreticians of language" (1934, engl. trans., p. 176).

The problem was obviously more critical in the case of impersonal sentences, where what is vacant is not just any role, but the one traditionally considered as fundamental: that of which we speak. Also, the ellipse had a solid position in the rethorical tradition, so much so that under its heading scholars had even legitimized a syntactic monster like the absolute ablative.

We may say that the process of dissolution of the very notion of ellipse, whose development after Saussure has been described by De Palo (2013), was underway already in the 1880s. In the second edition of his Prinzipien $\left(1886^{2}\right)$, Paul proposed a restricted notion of ellipse, examining elliptic sentences against the purely ideal standard of an expressive form that would convey a thought under all possible conditions to any possible listener. For Paul, a sentence can approach in varying degrees the theoretical standard represented by an absolutely complete sentence, endowed with unconditioned intelligibility. The language material used will always be limited to the minimum necessary for its local communicative success. Comprehension is therefore co-determined by the surrounding field, both verbal and non-verbal: the situation, the previous conversation, and the relative approximation of the speakers to a common frame of mind. Given these conditions, a single word may be as plain as a whole sentence (Paul $1886^{2}$; engl. trans., p. 351). Different expressions vary only in degree from this point of view. In expressions like he saw me and grew pale, or in fear and hope, not only there is no need to integrate the expression (he saw me and he grew pale, or in fear and in hope), but the very notion of supplying must "be wholly dropped, and replaced by that of single positing with plural reference" (ibid., p. 352). The same holds for expressions like il mar tranquillo e l'aria era soave ("peaceful the sea and sweet was the air", Petrarch), where "the first group remains incomplete until the common element is uttered, which [...] serves to complete the first and the second group at once" (ibid., p. 354). These examples and considerations show that "we must $[\ldots]$ cease to conceive what is commonly called a sentence as a closed and independent unity, and regard it rather as a link in a continuous series" (ibid., p. 352). 
Without following any further Paul in his multilingual array of examples of relative or apparent ellipses, we can conclude that what his analysis shows is: i) that no sentence can ever be a unit complete with all its elements, and ii) that even a sentence that comes closest to the theoretical standard of the complete sentence remains in any case only a part of a speech sequence that serves as its context.

This normalization of ellipse -no longer an exception but an intrinsic characteristic of sentences- occurs in the second edition of Paul's Prinzipien $\left(1886^{2}\right)$. In the first edition (1880, p. 71) Paul had only cursorily mentioned ellipses as anomalies, along with pleonasms and anacoluthons. This new view of the ellipse is theoretically associated with a new consideration of "the fundamental syntactical relations" (Die syntaktischen Grundverhältnisse : ch. vi, 1886², p. 99$124 ; 1920^{5}$, p. $121-150$ ), whose premise is that language never reproduces exactly the mental content of the speaker, and the reception of the message always requires an active role by the listener. Like elllipses and redundancy, semantic vagueness is also seen as an essential characteristic of language: "The linguistic expression [...] does not need to be equivalent to the psychical relation as it exists in the mind of the speaker, as it is to be produced in the mind of the hearer. It may be much less definite" (Paul 1886², engl. trans., p. 112). Language has various expressive modalities that filter the message from the speaker to the listener and only some of them are morphosyntactic (agglutination and inflection, word order, use of prepositions, conjunctions, auxiliary verbs). Other modalities are prosodic and phonosymbolic (energy of utterance, emphasis on certain words over others, pitch modulation, and time). Some modalities are determined by the natural course of ideas and feelings, other depend on the specific history of the various languages. Finally, the outcome of communication depends on the listener's capability of guessing the unexpressed relations with the verbal and situational context.

The ellipse appears less of an exception the more one establishes the principle that the primary type of verbal intercourse is not ongoing speech, but fragmentary speech (bruckstückweise Rede: Gabelentz 1891, p. 366) or even occasional speech in association with other activities (see O'Connel \& Kowal 2011, on Wegener). Gabelentz describes communication as an essentially deictic procedure, comparable to the one by which someone attracts our attention to an object, or hands us a tool we need, or directs us to a place where there is something we must see. Every preliminary deictic act becomes superfluous if we are already watching the object, if the tool is already in our hand, or if we are already in that place. The same holds for ellipses. In expressions like Already here!, All done!, etc., the missing words (you are..., it is...) are inferable from the context (Gabelentz 1869, p. 379). Every language is in some way defective, all recur to surrogates" (ibid., p. 381).

Gabelentz discusses ellipses with reference to the psychological role of the subject and predicate (1891, p. 365-373). Unless the expression has already acquired a complete meaning thanks to repeated use, as in expressions such as 
Halt! Fire! Help! and so on, it is up to the listeners to interpret the expression on the base of inferences from shared experience, possibly with the help of facial expressions and gestures. This holds for any fragmentary discourse, and the more the integration is effective among speakers, the more certainly will elliptic discourse achieve its goal.

In Gabelentz' opinion, ellipses must be seen as embryonic grammatical categories (1891, p. 368), a primitive stage of syntax, the fossil leftovers of a form of agglutination characteristic of the original human language. Speech resorts continually to this more economical and convenient medium, which certainly was one of its original verbal instruments. Like redundancy or unintentional allusion, it is an essential characteristic of languages: "We never say all that we think: we always leave it to the listener the task of adding this or that. Yet, many languages say $[\ldots]$ much more that is needed for understanding, certainly more than the speaker had thought and was thinking of saying" (ibid., p. 360). What is here under discussion is no longer the theory of syntax, but the general practice of symbolic interaction and the actual background against which it takes place.

\section{HOW TO FILL THE VACANT ROLE: THE QUEST FOR A SUBJECT}

Examples of elliptic sentences are frequently found in the literature on subjectless sentences. The latter were the true test of the distinction between the grammaticality and the logical validity of expressions, which was at the origin of the psychological approach.

The debate on impersonals was an important turning point in the history of theory. It evidenced the impossibility of describing the diverse syntactical relations found in various languages, if we use an indifferentiated concept of predication (see Samain 2008, p. 159). This had liberatory consequences both for the autonomy of syntactical studies and the development of semantics.

I shall limit my discussion to a single, but highly significant case, Sigwart's theory. This choice implies a degree of arbitrariness insofar as the line of study developed by Sigwart has some fundamental precedents, including Gabelentz, Wegener and Paul. However, his writings offer a particularly good vantage point from which the "logic" of impersonals may be viewed.

Sigwart is ignored by Elffers-van Ketel (1991) and cursorily dealt with by Graffi (2001, p. 102-103). Nerlich (1992) dismisses him as Urteilstheoretiker, but in so doing she touches upon an important aspect of the debate on impersonals as we shall see later on (p. 26). Kreiser (1996) deals with Sigwart's theory of proposition comparing it with those of Frege and Bolzano. Bühler does nor even include him in his list of language theorists who identify the subject as the expositional element of the sentence. The only recent sign of interest in Sigwart's position is Vonk (2014). Yet, Sigwart's contemporaries must have seen him as a leading figure, if Beck 
(1922), in summarizing the controversy on subjectless sentences, opposed the Sigwart Gruppe who supported the Zweigliedrigkeit (the necessary co-presence, at least implicit, of subject and predicate in every sentence) to the Miklosich Gruppe, who, invoking Brentano's psychological theories, supported the opposite thesis.

Sigwart agrees with other supporters of the Zweigliedrigkeit that the form of sentences does not have to reflect the structure of the categorical judgment (nor that of the existential one as maintained by Miklosich and Marty, who supported the opposite notion of Eingliedrigkeit). However, being genetically tied to the speaker's apperceptive processes, the sentence must contain at least implicitly the indication of appercipiendum, that of which one is speaking.

In the following pages I will examine three points of Sigwart's theory:

i) the distinction between the psychological and the philological approach to the problem of impersonals, with the implicit acknowledgment of the comparative autonomy of the historical development of languages from the psychological laws governing the behaviour of speakers.

ii) what I would define as the normalization of impersonal sentences, a process analogous to the normalization of ellipses already described. In this process, impersonals are presented as borderline cases, but not as exceptions, compared to utterances that only out of convention we consider complete. In fact, no utterance ever expresses the totality of a thought. There is never a one-toone correspondence between the semantic domain of the utterance and the psychological domain of representation.

iii) the consequent methodological choice, that is, the study of subjectless sentences in ordinary language, where "the analysis of the judgement [...] takes shape in the natural course of thought without skill or reflection on the part of the thinker" $\left(1889^{2}\right.$, engl. trans., p. 19). The focus is on the interpretive strategies thanks to which the listener transforms a grammatically incomplete expression into a complete semantic unit.

The first of the above points involves the epistemological problem of the relation between cognitive psychology and empirical linguistics. In this context, the existence of impersonals raises, for Sigwart, two related points. First, what do the people that use these expressions think, what kind of mental processes are they expressing when they choose these locutions? And second: How did specific languages acquire them? What is their history? (Sigwart 1888, p. 2-3). The first is a psychological question and can be dealt with only by reflecting on the mental processes of the subjects who communicate. The second question concerns the history of languages. A philological study cannot be certified by psychological laws, because the history of any language "follows ways that are entirely different from those of its original creation and gradual construction" (ibid., p. 4). Even a philological reconstruction, on the other hand, cannot go beyond certain boundaries. Nothing, for example, testifies to the fact that subjectless sentences were embryonic forms from which the subject-predicate sentences originated (as 
maintained by Gabelentz). Indeed the frequency of impersonals does not seem to have decreased over time, as evidenced for example by a comparison of modern German, which abounds in impersonals, and the language of Homer, which contains very few instances of them (ibid., p. 8-9). Psychology may explain the present usage of a language but can never be used to reconstruct its history. For Sigwart, any a priori theory that starts from the forms of judgement to derive the forms of the sentence and its historical realizations, implies the faulty premise that one can go back to an original thought untouched by language.

I will now proceed to discuss the second point mentioned above, the normalization of subjectless sentences. Sigwart's premise on this point is that an utterance, no matter how grammatically complete, never expresses the totality of a mental content, and there is no language that does not require the listener to make inferences. Sigwart recurs to a latinism (subintelligiren) to indicate the unconscious or semiconscious inferences thanks to which the listener mentally integrates the text. The nature of linguistic forms is so varied that one can never infer the completeness or incompleteness of the corresponding thought from the presence or absence of a verbal constituent $(1888, \mathrm{p}$. 4). The conclusion is that subjectless sentences do not differ from syntactically complete sentences except for the fact that they require from the listener a more active interpretive role. They are only a different result of the general processes connecting any sentence of a natural language to the mental functions of the speakers. In every language "not only the spatial and temporal order of the real world, but even the much more intimate connection of things with their properties, states and actions seems to dissolve, like a mosaic dividing into its individual tiles". To produce meaning we have to reconstruct that mosaic, to restore some kind of order and connection among representations. This cannot be done in the absence of the speaker's further hints or the listener's inferences from local circumstances (ibid., p. 10-11). The game is entirely based on the interplay of the verbal forms available in the natural language, their context, and the modalities of perception.

The third point among the ones listed above concerns Sigwart's method and is a consequence of what we have said up to here. If the peculiarity of subjectless sentences lies solely in the greater cooperation they require on the part of the listener, the analysis must turn from the mental processes of the speaker to those of the listener.

Sigwart starts with a corpus of impersonals, he analyzes their form and then, case by case, theoretically reconstructs the mental processes of the speakers and hearers. His assumption is that, while impersonal sentences can be distinguished on the basis of common superficial features, there is no clear-cut boundary between thoughts that are expressed through impersonal forms, and thoughts expressed through sentences based on subject and predicate. Therefore, we cannot treat them as a different kind of judgment (1888, p. 5-6). We have to ascertain case by case how, starting from the verbal and situational context, the listener 
reconstructs the unexpressed subject. This was an implicit criticism of Miklosich and the Brentanian school, who considered subjectless sentences as a special class of sentences, formally corresponding to existential judgment.

\section{APPARENT IMPERSONALS}

Sigwart's analysis starts from the simplest and most general case, that of verbal expressions of a perception, where by "perception" (Wahrnehmung) he means not only the registration of a stimulus, but that of any information coming from the environnement. A sentence like this is $X$ (a denomination-judgment, or Benennungsatz) expresses the conformity of an object to the representation I already possess. Even the communication of this elementary act of recognition implies the listener's cooperation. The demonstrative pronoun, like a concomitant deictic gesture, or the use of an imperative formula like Sieh da! ("Look!"), all serve to favor the synthesis of the present perception with the representation designated by the word (1888, p. 13-14).

Denomination-judgments are the simplest form of mental synthesis: the type of synthesis enacted by infants when they learn names by associating them to deixis. Denomination-judgments are those "in which all human judgment begins, those in which definite objects of sense intuition are recognized and named" $\left(1889^{2}\right.$, engl. trans., p. 51). Denomination may be expressed in predicative form even in the absence of a subject: indeed, this is the way children usually proceed, through a verbalized act of recognition in which "it is only the verbal expression which is incomplete, not the mental process" (ibid.). A mental act is incomplete, instead, when the predicate is missing, for example when we recognize an object for which we do not have a word. "It is indeed essential to the predicate that the idea belonging to it should be none other than the meaning of the word, the ideal content which is connected with the word as such and has thus become ours [... and] can be reproduced by and with spoken words" (ibid., p. 52). Put in another way: while the subject can be reconstructed thanks to non-verbal semiotic procedures, such as gestures and contextual inferences, the reproducibility of the idea expressed by the predicate, and therefore the completeness of the judgement, requires the lexicalization of the corresponding idea.

Like Steinthal's Erkennungksatz, Sigwart's Benennungsatz is a pre-grammatical thought. It is only when one goes from the immediacy of the denominationjudgment to the explicit expression of the properties or actions of the subject, that the analysis of perception must confront itself with the paths "that the language has pre-traced through its distinction between noun, adjective and verb" (1888, p. 15; see $1889^{2}$, engl. trans., p. 60). Sigwart describes various types of synthesis and the movements of thought that produce them. For example, the correlation between a subject and a predicate when we identify an object moving in space as a bird who 
has just taken flight. Or the act through which we realize the salient element of a perception. Or the perception of a predicate as absolute, for example when we see something flashing on the horizon but we do not know whether it is a light, a fire, or the reflection of the sun, or something else, and we can only say: it's flashing. The latter is an example of impersonal synthesis.

We are dealing here with an important aspect of Sigwart's criticism of the judgment model. The preeminence of a subject conceived as substance is a prejudice that prevents us from seeing how the aspect that corresponds to the predicate is often the first one we become aware of, as in the example of the unidentified flash of light. Only later does a further act of object-predicate synthesis generate a noun.

Philosophical logic tends to reduce all sentences to the judgment model. But language expresses different kinds of representational synthesis by different kinds of sentences. Subjectless sentences are only one particular kind among others. The roles played by the subject and predicate in the verbal synthesis of representations depend in part on the sensorial modalities involved. The synthesis that generates the impersonals (as in the example of the flash of light) generally occurs when we are dealing with delimited phenomena, which gradually stand out in a context until they become perceived and more or less identifiable. When we say that the object we see is a bird in flight, we have been able to identify the subject in the context of a succession, through the various phases of the perceptive process (bird on branch, then bird in flight). The second example is different, because the flash of light appears as something that flashes before we are able to tell what is flashing.

The synthesis of the impersonals is less frequent in multi-sensory experiences (when for example I hear a sound and simultaneously see the object that produces it). It is more frequent when only one sense is involved (seeing "something" that shines on the horizon). It is less frequent when a past experience provides clues about the source of the perception (I hear a sound and recognize it as a human voice, I hear a barking and I know $a \operatorname{dog}$ is barking). It is more frequent when there is no stable association (a noise in the woods can suggest various possible subjects), in which case, we can only generically refer to something. We know there is something specific behind it, but we do not know what it is.

Sometimes however the ellipse of the subject, as other kinds of ellipses, is used to comply with economy of expression, a principle that Paul had introduced in the same context (Sparksamkeit im Ausdruck: $1886^{2}$, ch. xviii). The subject is the essential datum in the perception of the speaker, but he may omit it when it is evident from the context: as when, close to the railway station, I say "it's blowing" without mentioning the source of the sound. The direct reference is the perception of the signal as such, thanks to the significance it acquires in this context (Sigwart 1888 , p. 27-28).

The normalization of impersonal sentences as an expressive modality among others implies also the normalization of the impersonal pronoun par excellence: the neuter sigular es $(1888$, p. $20 \mathrm{ff}$.). Es is an impersonal pronoun in terms of 
its lexical meaning (Bedeutung). As such, it may be simply considered as an equivalent of etwas, "something", or ich weiss nicht was, "I do not know what". It is neither more nor less indeterminate than words like this or that, or expressions like $a$ thing, which can also apply to objects or events that are perfectly known and defined. It is neither more nor less context-dependent than other pronouns and, like them, can have an anaphoric function, referring to a noun already mentioned by the speaker. Or it can refer, in a way that is perfectly intelligible for the listener, to the overall situation. In these cases, it functions exactly like a masculine or feminine pronoun, as in the case of er kommt, where er indicates an undefined masculine subject and is variously interpreted depending on the context: the teacher in a classroom, the train (der Zug) in a station full of waiting passenger, etc. Finally, the neuter pronoun can also indicate an overall subject which does not need to be made verbally explicit, as in expressions like "it was boring", "it was fun", which refer in general to the occurrence one is speaking of, independently of the details. But es can also be used as direct object as in: Lass es jetzt gut sein..., Ich sehe es kommen..., etc. ("Let it go...", "I see it happening"). Finally, it is used sometimes to indicate words to be avoided out of decency or superstition (1888, p. 27-28, passim).

Other ways to reproduce different types of representational synthesis are the use of substantive infinitives (or progressive form in English) and the passive voice. Infinitives can be used to present acts or processes in an absolute fashion, without mentioning the agent. Take expressions such as: "Zum Speier im Saale da hebt sich ein Klingen, mit fackeln und Kerzen ein Tanzen und Springen" (L. Uhland: "a music playing... a dancing and hopping"), or: "es enstand ein Laufen und Durcheinanderennen, allgemeines Begrüssen und Händelschüttern" ("it was all $a$ running and crossing and waving and handshaking"). The action "is more easily detached from the subject, and becomes itself the object of thought, when one does not refer to a countable number of subjects [but] to a collective action" (Sigwart 1888, p. 36).

The passive voice - Es wurde gespielt, dann gespeist, dann getanzt - produces a collective subject of the performed actions ("there was playing, then eating, then dancing"): an unmentioned subject whose generic identity is nevertheless evident (the whole of the guests). Thus, "the common action takes on in itself an autonomous import" that the passive verb brings to light by leaving the position of the subject empty. The listener who were to insist on the speaker filling in this position would obtain a tautological response -Tänze wurden getantzt ("dances were danced")or else a misleading specification, such as "a waltz, a minuet..." (Sigwart 1888, p. 38). Another example: Um 7 wird aufgestanden, um 8 gefrüstuckt... Here we have a collective subject of future actions ("getting up at 7, breakfast[ing] at $8 . .$. "). The subject is not mentioned, but can be generically identified as the perceived global state of affairs. The verbal ending is impersonal in the way deictic too are impersonal, which "denote nothing definite by themselves or by the mere sound 
of the word", but express "a reference to the thinking and speaking subject (or to that of which he speaks), and they do not therefore become the sign of a definite idea until this reference is understood by means of actual intuition" $\left(1889^{2}\right.$, engl. trans., p. 41).

In some cases, the efficacy of enunciation is due precisely to the fact that it lacks a determinate subject. In this way, the attention is not so much on the agent as the overall physical phenomenon we perceive. Es wallet, und siedet und brauset und zischt ("It foams and swells and bellows and sprays..."): here we are not describing the sea as much as our "global sensation" of it (Sigwart 1888, p. 36).

In a certain sense, such sentences can be considered as lacking a subject. The thing-subject (Ding-Subject), in which the phenomenon manifests itself or which produces it, is not expressed in words with their materiality and individuality, nor is it explicitly present in thought. In another sense, however, from the perspective of thought, subject and predicate are explicitly indicated. The subject is the actual intuition that touches our senses. The predicate gives a name to that intuition, and refers with its ending to an actual and present event (ibid., p. 37).

As one can see, none of these reasons for using impersonal is of a logicalgrammatical nature. Instead, they all depend, for their form, on the particular type of perceptual synthesis they express and, for their meaning, on the situation of the enunciation. In short, in most cases, what appear as impersonal sentences are actually "normal" sentences, where -especially in the informal style of conversation- the neutral pronoun stands for a whole complex of things or events to which the speaker refers, which the listener can easily infer from the context. These are not, therefore, real impersonals.

\section{ARE THER ANY REAL IMPERSONALS?}

Up to here, Sigwart has performed a survey of impersonal sentences which can be easily reduced to complete forms. Their analysis evidences the various strategies adopted by natural languages to express the various types of mental synthesis. The fact that the missing constituents can be explicitly reconstructed qualifies these sentences as ellipses more than real impersonals. A different case is that of the sentences that really lack a subject. These express phenomena or states that are perceived as something that occurs independently of our will or actions, like a force that dominates us, like the action of a foreign agent, a global state that is impossible to analyze. These phenomena can be either external or internal. Examples of the first are meteorological conditions such as es blitzt, es donnert, es schneit... ("it is lightning, it thunders, it is snowing"). Examples of the second are internal states such as cold (es friert mich), fear (es ist mir bang), disgust (es ekelt mir), etc. (ibid., p. 7, 3). 
There is only an imperceptible transition between apparent and real impersonals, depending on the different perspective selected to describe the same subjective state. In sentences like es ist kalt, es ist warm, etc., a real implicit subject may be contained (the air, the wind, etc.). Not so in the corresponding expressions mir ist kalt, mir ist warm, etc., where the cold, the warmth, indicate absolute conditions. In the first case (apparent impersonals)

the predicate is foregrounded to the point of becoming independent, whether we use the nouns warmth and coldness as abstract terms that require a genitive -the coldness of the wind, the warmth of the water- or as concrete terms, as if they were a sort of substance that surrounds and envelops us, or autonomous forces that exercise their effects (Sigwart 1888, p. 25).

In the second case (real impersonals), the subject remains in the background,

on the border beyond which the pronoun (or, respectively, the inflection) no longer expresses something that can be in any way conceived or represented. What is truly present and alive in our representation is only the sensory impression expressed by the adjective or the verb. As a thought subject, [...] all we are left with is the present perception: the luminous phenomenon, the voice, what happens that can be perceived. Our conscious mental content cannot be analysed $[\ldots]$ as a thing with its properties, a thing with its action, and even if we know the pertinent thing, we stop at the pure datum or factual situation without trying to express in our enunciation the relation that the datum has with a thing (ibid., p. 26-27).

The only discriminant between apparent and real impersonals is that, in the second case, even the request to determine the real subject makes no sense (Sigwart 1888, p. $24 ; 1889^{2}$, engl. trans., p. 64 ), as if one were to ask who? or what? in reply to the statement it's raining.

The reference to a subject-thing which is contained in the pronoun of modern languages is $[\ldots]$ an empty customary form; we cannot ask "what lightens?" and answer "it" in the sense of a thing however indefinite. All that the impersonal proposition can do is to name the phenomenon present at the moment: the subject is nothing more than the particolar flash of light itself (ibid.).

The use of impersonals can also be dictated by a greater interest in the predicate, rather than the ignorance of the subject. In the expression es brennt! ("fire!") the implicit subject is not the thing that is burning, but the fire itself. Impersonals can also be dictated by the speaker's intentions. For instance in the case of imperative or optative sentences such as Silence!, which do express a propositional attitude of the speaker (I want you to be silent), whose purpose, however, is not the direct communication of this fact, but influencing the interlocutor's behavior. In this case the act of reception is asymmetrical in relation to the utterance: the listener receives a message that asks him to be silent, not a message that communicates that it is true that the speaker wishes the listener to be silent $\left(1889^{2}\right.$, engl. trans., p.17-18, footnote). The conclusion, once again, is that the grammatical form is never an infallible indication of the nature of the sentence. 


\section{CONCLUSION}

The story I have told is incomplete, because it only presents the point of view of the followers of the Zweigliedrigkeit. I have not dealt with the studies of the opposite side, the upholders of the Eingliedrigkeit, starting from the second edition of Miklosich's essays on impersonals (1883). In that essay, Miklosich appealed to Brentano's theory of the existential judgment to bolster his position. This support was indeed explicitly provided shortly thereafter by Brentano (1883), who evidently saw Miklosich's work as a philological confirmation of his theory. This mutual support was the starting point for Anton Marty's long, detailed and harsh polemic against the Zweigliedrigkeit thesis.

The development I have described began with the search for a type of synthesis different from that of the logical judgement but equally capable of explaining the unitary and dual nature of the sentence. In the context of his critique of "logical" grammar, Steinthal had elaborated the notion of the psychological or apperceptional judgment, verbally articulated in the Erkennungsatz. Sigwart had started from a similar position, with his notion of Benennungsatz as a form of preverbal synthesis somehow predisposed to generate the sentence. Even though syntactically incomplete, the Benennungsatz can neverthless be reduced to a complete unity, thanks to the synthesis to which the listener is led by the co-text and context in conversational interaction.

Even if Sigwart does not mention him, one can easily detect in his argument the presence of Wegener's ideas and even of his examples. Wegener had never participated directly in the debate on impersonals though he had contributed to it extensively in an indirect fashion, by his stress on the interpretive role of the listener. After 1900, he offered the following comment on the controversy, which sounds like an invitation to bring the discussion to an end.

As we know, logicians did not acknowledge in the content of the generic subject es the presence of a subject and therefore believed that one should speak of logical judgments as lacking a subject. Of course, in itself, es is an empty expression, empty like all indications (Hinweisung); but any indication stimulates the listener to provide on his own the content in question on the basis of the situation, [...] so long as it conforms to the representational content of the predicate. [...]. I am referring to the question that follows from all this, which is very important from the perspective of the history of linguistics: the fact that the subject $[\ldots]$ is determined [...] by the predicate that follows it. The thing is so simple that it is difficult to understand how it could have generated so many misunderstandings (Wegener 1921, p. 20-21 [emphasis L. F.]).

This short and late intervention is found in Wegener's essay on one-word sentences, published posthumously but written shortly after 1900. Its significance is clear for all those familiar with the Untersuchungen. More than upholding the implicit option for Zweigliedrigkeit, Wegener seems interested in demonstrating the irrelevance of the question from the perspective of linguistics, and relegating 
it to Urteilstheorie (see Nerlich: above, p. 17). The Urteiltheoretiker had focused the discussion on the alternative between two types of judgments (predicative/ non-predicative). The important question, instead, in Wegener's opinion, is the capacity of language to suggest what it does not say through what is said, which is essential to its communicative function.

Wegener's invitation to distinguish the urteilstheoretisch aspect of the debate from the linguistic one proper is a good starting point for clarifying a problem in which the two aspects, the logical and the linguistic one, are so magmatically combined.

\section{BIBLIOGRAPHY}

\section{PRIMARY SOURCES}

Brentano, Franz, 1883. « Miklosich über subjektlose Sätze », Wiener Zeitung, 13, 261.

Bühler, Karl, 1934. Sprachtheorie. Die Darstellungstheorie der Sprache, Frankfurt a.M., Klostermann [engl. trans., Theory of Language. The representational theory of language, Amsterdam/Philadelphia, John Benjamins, 1990].

Gabelentz, H. Georg C. von der, 1869. «Ideen zu eine vergleichende Syntax. Wort- und Satzstellung », Zeitschrift für Völkerpsychologie und Sprachwissenschaft, 6, 376-384.

- 1874. « Weiteres zur eine vergleichenden Syntax. Wort- und Satzstellung », Zeitschrift für Völkerpsychologie und Sprachwissenschaft, 8, 129-165, 300-338.

- 1891. Die Sprachwissenschaft. Ihre Aufgaben, Methoden und bisherige Ergebnisse, Leipzig, Weigel Nachfolger [Leipzig, Tauchnitz, 1901²; Repr. Tübingen, Narr, 1969, $\left.1972^{2}, 1984^{3}\right]$.

Jacobi, Friedrich Heinrich, 1791. Letter to Erhard O***, Werke, I, Leipzig, Fleischer, 1912, 227-253.

Miklosich, Franz, $1883^{2}$ [1875]. Subjektlose Sätze, Wien, Braumüller.

Paul, Hermann, 1886 ${ }^{2}$. Prinzipien der Sprachgeschichte, Halle, Niemeyer [Engl. trans. $1891^{2}$, Principles of the History of Language, London, Swan Sonneschein]; $1920^{5}$ (Repr. 1995).

Reinhold, Karl Leonard, 1812. Grundlegung einer Synonymik für den allgemeinen Sprachgebrauch in den philosophischen Wissenschaften, Kiel, Schmidt.

Sigwart, Christoph, 1888. Die Impersonalien. Eine logische Untersuchung, Freiburg i. B., Mohr.

- 1889². Logik, I. Die Lehre vom Urteil, vom Begriff und vom Schluss, Freiburg i. B., Mohr [Engl. trans., Logic, I. The Judgment, Concept and Inference, London, Swan Sonneschein/Macmillan, 1895].

Steinthal, Heymann, 1855. Grammatik, Logik und Psychologie. Ihre Prinzipien und ihr Verhältnis zueinander, Berlin, Dümmler [Repr. Hildesheim, G. Olms, 1968].

- 1881. Abriss der Sprachwissenschaft. I. Einleitung in die Psychologie und Sprachwissenschaft, Berlin, Dümmler [Repr. Hildesheim, G. Olms, 1972].

Wegener, Philipp, 1921. " Der Wortsatz», Indogermanischen Forschungen, 39, 1-26.

\section{SECONDARY SOURCES}

Beck, Ernst H.F., 1922. Die Impersonalien in sprachpsychologischer, logischer und linguistischer Hinsicht, Leipzig, Quelle und Mayer.

De Palo, Marina, 2013. «L'ellipse en contexte », Paradigmi, XXXI, 1, 165-176.

Elffers-van Ketel, Els, 1991. The Historiography of Grammatical Concepts. 19th and 20th century. Changes in the subject-predicate conception and the problem of their historical reconstruction, Amsterdam, Rodopi. 
Graffi, Giorgio, 2001. 200 Years of Syntax, Amsterdam/Philadelphia, John Benjamins.

Kreiser, Lothar, 1996. « Das logische Problem der Impersonalien und seine Behandlung durch Christoph Sigwart », Volker Hertel et al. Hrsg., Sprache und Kommunikation im Kulturkontext, 121-1345.

Nerlich, Brigitte, 1992. Semantic Theories in Europe. 1830-1930, Amsterdam/Philadelphia, John Benjamins.

O'Connel, Daniel \& Kowal, Sabine, 2011. « Sources of History for a Psychology of Verbal Communication », Journal of Psycholinguistic Research, 40 (1), 29-47.

Samain, Didier, 2008. "Langues et métalangages : verbe et prédication chez Heymann Steinthal », Patrick Sériot et Didier Samain (éd.), La structure de la proposition : histoire d'un métalangage, Cahiers de l'ILSL, 25, 147-166.

Vonk, Frank, 2014. «Das impersonale Urteil. Eine logische und sprachwissenschaftliche Diskussion im ausgehenden 19. Jahrhundert », Beiträge zur Geschichte der Sprachwissenschaft. 